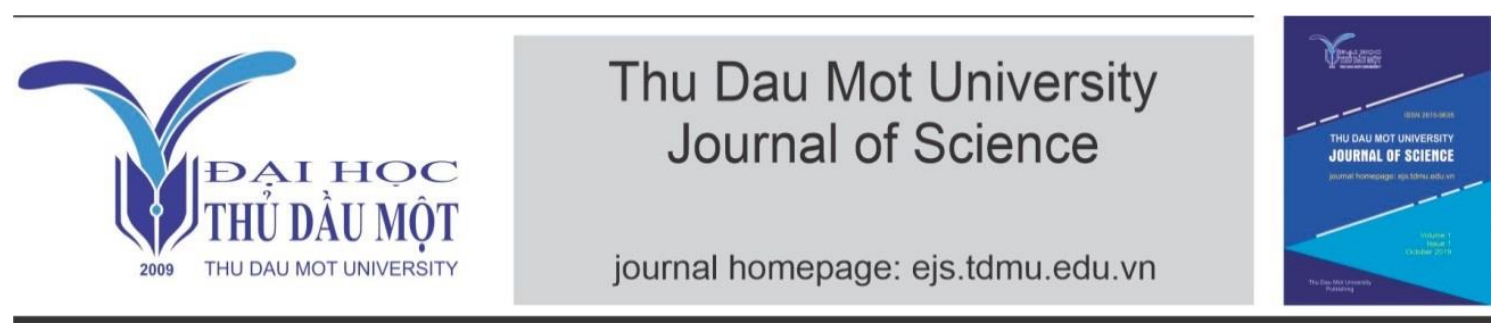

\title{
Changes in Vietnamese language from globalization and localization
}

\author{
by Võ Kim Hà (Thu Dau Mot University)
}
Article Info: $\quad$ Received 31 Mar. 2021, Accepted 2 June 2021, Available online 15 June 2021
Corresponding author: havk@tdmu.edu.vn
https://doi.org/10.37550/tdmu.EJS/2021.02.204

\begin{abstract}
The paper demonstrates the role of globalization and localization in the process of Vietnam's interaction and integration with other cultures, causing changes in Vietnamese language. Globalization is defined as the free movement of goods, services and people of the worldwide scope across the borders of countries, resulted from the opening up of the global economy and advances of technologies. The increasing interconnectedness and integration of the economies of the world furnish more influx of information among countries which do not have anything in common and Internet and social media well contribute to such spread. Not only the pros but the cons of globalization are used to explain the part of localization as the entire process of adapting a product or content to a specific location or market. The paper indicates localization as the Vietnamese people's endeavor to adapt Vietnamese language to the world while protecting and enhancing the national characters. The differences between localization and globalization are analyzed to demonstrate the value and requirements of localization in the present time. The influences of Sino-Vietnamese and French language are also found out as evidences of the phenomena. The changes of Vietnamese language from globalization and localization are illustrated with devices, ideas and images referring to the objects, actions or ideas.
\end{abstract}

Keywords: Vietnamese language, globalization, localization

\section{Introduction}

With hundreds of countries in the world, interaction and integration among peoples, governments and organizations of the various nations certainly occur and unavoidably 
lead to interdependence of the economic, social and cultural aspects. In Vietnam history, with the foreign invasions lasting hundreds of years, such interdependence has effects on Vietnamese culture in general and on Vietnamese language as a cultural element in particular. The study proves the striking impact of globalization and localization on the changes of Vietnamese language.

Two research questions can be raised to get good results for analysis.

$1 /$ What is the difference between globalization and localization?

2/ How has Vietnamese language changed under the influence of globalization and localization?

\section{Literature Review}

\subsection{Definition of globalization}

Globalization is defined as "growth to a global or worldwide scale", referring to the situation in which the whole world behaves as a single place. Based on the economic sense, Cambridge Dictionary considers globalization as "the increase of trade around the world" or "a situation in which available goods and services, or social and cultural influences, gradually become similar in all parts of the world". Globalization was first used as human experience in education in 1930 in the publication entitled "Towards New Education". For Barnaby J. Feder in "Theodore Levitt, 81, Who Coined the Term 'Globalization', Is Dead", the economic sense of globalization appeared at least as early as 1981, about forty years after the uses of globalization in other senses. The concept of globalization has inspired various projects, articles and discussions in different areas to find its value and usage context. From a social viewpoint, the sociologist Martin Albrow describes globalization as "all those processes by which the people of the world are incorporated into a single world society".

If Swedish journalist Thomas Larsson, in "The Race to the Top: The Real Story of Globalization", romantically sees globalization as "the process of world shrinkage, of distances getting shorter, things moving closer", then in the book entitled Global Transformation, David Held, Professor of Politics and International Relations at Durham University, and his co-writers state globalization as "transformation in the spatial organization of social relations and transactions-assessed in terms of their extensity, intensity, velocity and impact—generating transcontinental or inter-regional flows".

In such globalization, when relations and transactions may occur among different regions, even cross-border nations, economic interdependence of national economies surely increases. In 2000, the International Monetary Fund (IMF) determined four basic aspects of globalization: trade and transactions, capital and investment movements, migration and movement of people, and the dissemination of knowledge. These four 
aspects can store up all the globalized areas.

\subsection{Definition of localization}

Localization is derived from the term "locale", which is defined in Oxford Dictionary as "A place where something happens or is set, or that has particular events associated with it." Localization is then considered as "the process of making something local in character or restricting it to a particular place" (Oxford Dictionary). Since globalization is considered on an international scale, localization is the process in a specific region or country, the two can occur simultaneously but localization can be considered as a concept opposite to globalization.

In reality, these two processes: globalization and localization are not dichotomies, not opposed parts.

In Vietnam, globalization and localization can be understood in a different way. In the history of thousands of years, Vietnam had to battle and suffer from foreign invasions such as Chinese, French, American. The domination governments certainly wanted to propagate their languages as "a national language" in Vietnam and Vietnamese people were forced to get some foreign scripts. The forced demand to use foreign languages can be considered as a form of globalization, but how to use those borrowed terms was the way of localization to protect national characters. Under the influence of foreign invasions, of different violent incidents, of economic interdependence and other contingent issues, Vietnamese people had to import foreign languages and then change the foreign terms in some way to make them become their own Vietnamese.

After using foreign languages, Chinese, French or English, for a long time, Vietnamese people can get and then Vietnamize borrowed foreign languages in some ways. The Vietnamized terms became a kind of official script used in cultural, politic and social activities in Vietnam.

Once Vietnamized terms become Vietnamese and are comfortably used in life, localization demonstrates to be a necessary process to maintain national characters in Vietnamese language.

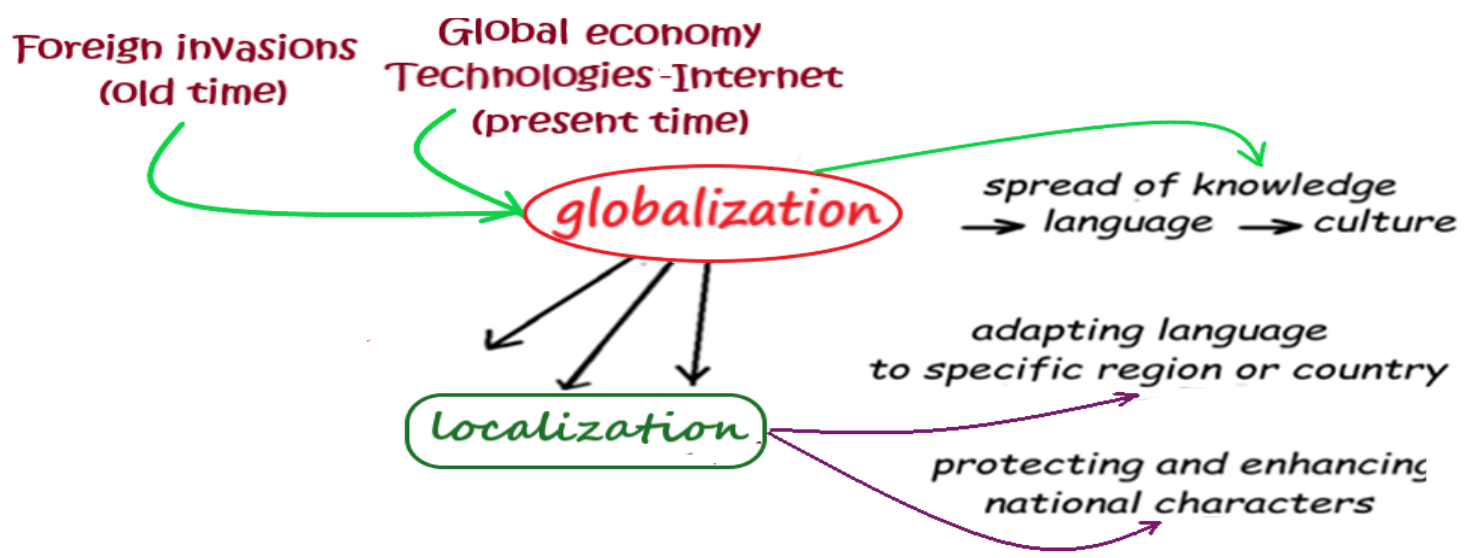

Fig.1 Globalization and Localization 


\subsection{Literature Review}

A variety of researches, conferences, articles have concerned Vietnamese Language and Vietnamese culture in interaction with foreign languages, especially Chinese.

The Chinese domination for over a thousand years led to the use of lots of Chinese terms in Vietnam, but many Chinese terms were Vietnamized in all the three aspects: phonetic reading, meaning and extent of use.

$70 \%$ of Vietnamese vocabulary are Sino-Vietnamese and the researches have tried to find out the ways of Vietnamizing the borrowed Chinese terms and how to construct Sino-Vietnamese and Southern characters. A series of articles in Tuoi Tre newspaper written by researchers of Literature and Linguistics described the process of establishing and developing of Vietnamese script. The book written by Pham Van Hai, a researcher in University of George Washington, entitled "Chũ Hán và tiếng Hán-Việt" (Chinese and Sino-Vietnamese) and used as a course book for Da Lat University furnishes basic and necessary knowledge about Sino-Vietnamese.

\section{Result and Discussion}

What was Vietnamese language before the $1^{\text {st }}$ Chinese domination or before 111 BC? According to "Tan Han Thu", an ancient history book of China coming forth in the Eastern Han domination in the $2^{\text {nd }}$ millennium BC, Vietnamese people had their own script looking like tadpole flocks. That tadpole-like script might not be perfected yet, but it was expired and annihilated.

No data remained about other Vietnamese scripts right after tadpole-like script and some researchers of popular culture tried to decode the traits, patterns and images carved on Ngoc Lu bronze drums in Dong Son culture. They believed those carved traits could express a special language.

TABLE 1: Relationship between language and political situation in Vietnam

\begin{tabular}{|c|l|l|l|}
\hline Time & Politic situation & Spoken language & Written language \\
\hline 111BC-39AD & Chinese domination & Vietnamese/Chinese & Chinese \\
\hline 939-1651 & Independent Monarchy & Vietnamese/Chinese & Chinese/Southern characters \\
\hline $1651-1861$ & Independent Monarchy & Vietnamese/Chinese & $\begin{array}{l}\text { Chinese/Southern } \\
\text { characters/Vietnamese } \\
\text { script/Initial Vietnamese script }\end{array}$ \\
\hline $1861-1945$ & French domination & $\begin{array}{l}\text { Vietnamese/Chinese/Fr } \\
\text { ench }\end{array}$ & $\begin{array}{l}\text { Chinese/Southern } \\
\text { characters/Vietnamese } \\
\text { script/French }\end{array}$ \\
\hline $1945-$ now & Independence & Vietnamese & Vietnamese script \\
\hline
\end{tabular}

(Source: John De Francis, 1977)

\subsection{Chinese and Sino - Chinese}

\subsubsection{Chinese domination}


There were two continuous dynasties from the beginning of Au Lac state:

- The first is Hong Bang dynasty, lasting 2621 years (from 2879 BC to 258 BC)

- The second is Thuc dynasty (from $257 \mathrm{BC}$ to $207 \mathrm{BC}$ )

- The third was Trieu dynasty (from $207 \mathrm{BC}$ to $111 \mathrm{BC}$ )

Some historians stated that there were only two dynasties before the first Chinese domination, that means Trieu dynasty formed by Trieu Da belonged to Chinese domination, because Trieu Da was a Han (Chinese) living in Chan Dinh, Ha Bac province, China.

After these two dynasties, Trieu Da took two districts Que Lam and Tuong Quan and in 207 BC formed the Trieu dynasty (207-111 BC) in Nam Viet country. 18 years after, Trieu invaded Au Lac state under An Duong Vuong dynasty.

Other historians, such as Ta Chi Dai Truong, Vu The Khoi and some others, determined the reasons for choosing Trieu dynasty as the third dynasty, after Hong Bang and Thuc dynasties.

Trieu Da, despite being a "Han", performed the policy of settling life for Viet people: using Lu Gia as "Thua Tuong" (Chancellor), who was called as "a Viet person" in Tu Ma Thien Chronicles, developing economy and culture to transform Linh Nam to a brilliant region, accumulating Chinese and Vietnamese cultures, even battling Chinese invasion.

Lu Gia was a popular administrator and Trieu Da actively studied the Viet customs and habits.

According to $\mathrm{Vu}$ The Khoi (2006), Trieu and $\mathrm{Lu}$ were the earliest representatives of ancient Chinese-Vietnamese families concerned in the history. Vu The Khoi also claimed that was the favorable factor to motivate the spread of Chinese language and the Chinese-Vietnamese cultural exchange.

Many Vietnamese historians, such as Ta Chi Dai Truong, Vu The Khoi and others, admitted the viewpoint about accumulation of the two Chinese-Vietnamese cultures under Trieu dynasty. Even the national historical book, "Dai Viet Su ky Toan thu", wrote about Trieu dynasty as a formal dynasty of Dai Viet country.

Therefore, in the history of Vietnam, there were two Chinese periods of domination as follows:

a.The first Chinese domination (111 BC-39 AD): lasted 246 years mainly under Western Han.

3 years of the mighty Hai Ba Trung dynasty (from 40 to 43) separated the two Chinese dominations and after the failure of Hai Ba Trung, Viet land had to be under Eastern Han domination again.

b. The second Chinese domination (43-544): lasted 501 years and consisted of the 
different Chinese dynasties: Eastern Han (43-220), Ngo (220-280), Tan (280-420), Tong (420-479), Te (479-502), Luong (502-544).

The Eastern Han government facilitated the domination with the different policies:

- Moving a number of Han people from the northern area to Giao Chau, especially in the troubled political situation in China in late $2^{\text {nd }}$ century. Chinese residents' life in Giao Chau became more and more complex and such situation was appropriate for the policy of assimilation into Chinese.

- With the elimination of old rules and customs and habits of Viet people in Giao Chau, the Eastern Han government deployed series of rules and customs of Chinese people, forced Giao Chau people to obey the Chinese domination government to easily govern and increase the policy of assimilation.

- In cultural and social aspects, the Eastern Han government of domination opened schools teaching Chinese language, circulated Confucianism with the aim of assimilation into Chinese,

After Chinese domination, Viet people emerged to ask for independence and Tang dynasty in China had to accept Khuc Thua Du as governor. In 939, under Ngo Quyen's leadership, Viet people obtained total independence.

Therefore, from the time of formation of a country with clear boundaries to 939 AD, Viet people had to suffer from the two Chinese dominations lasting almost a thousand years.

\subsubsection{Formation of Sino-Vietnamese}

The policy of assimilation into Han people and to Chinese scripts of the Chinese governments of domination brought a good result, that was Viet people's creation of Sino-Vietnamese.

Chinese language has not been in the curriculum of Vietnamese schools, like Japan or Korea, but it is estimated that $70 \%$ of Vietnamese vocabulary is Sino-Vietnamese. Only some Chinese words about dishes have been read with Chinese phonetic reading, such as hủ tíu, thèo lèo, xá xíu, hoành thánh, xuổi cảo,...

The Chinese domination governments tried to assimilate and transform Viet people to Han people and to make Han script "a national language" in Giao Chau, but in reality, Viet people assimilated Han script and created part of their own language called SinoVietnamese.

And now, in China, almost all of personal names, land names are written in SinoVietnamese, whereas Vietnam still write the Chinese personal names based on SinoVietnamese, such as: Lo Tan, Thuong Hai or Bac Kinh, instead of the transcribed names: Lu Xun, Shanghai or Beijing...

Two notable characteristics: first, in the Chinese dominations, Chinese script were written in books, documents, but Vietnamese and Sino-Vietnamese were always used in 
daily activities; second, Viet people borrowed and changed only simple Chinese terms and did not imitate basic grammatical rules, such as the order of adjective and noun.

Vietnamizing Chinese characters resulted in three kinds of Sino-Vietnamese:

1/ Sino-Vietnamese: based on Chinese phonetic system in Tang dynasty imported to Giao Chau about the $7^{\text {th }}-0$ century. Gradually, Viet people transformed the Tang phonetic system to their own reading, so that Sino-Vietnamese were the combination between Chinese original terms and Vietnamese phonetic reading, for example, "Đường" (Tang), "Minh" (Ming)

2/ Classical Sino-Vietnamese with old Chinese phonetic reading: some original Chinese terms borrowed before Tang dynasty were not systematic and not spoken with SinoVietnamese phonetic reading.

3/ Vietnamized Sino-Vietnamese: Chinese original terms borrowed in Tang dynasty but changed in accordance with the rules of Vietnamese phonetic variation.

Classical Sino-Vietnamese and Vietnamized Sino-Vietnamese were usually in one type commonly called originally Chinese Vietnamese.

The policy of assimilation into Han language of some northern dynasties, the measures performed for such policy and interaction among Chinese and Viet people in life demonstrate a type of forced globalization in some way, whereas the creation of SinoVietnamese in the process of interaction and integration among Chinese and Viet people proves localization to enhance Viet national characters.

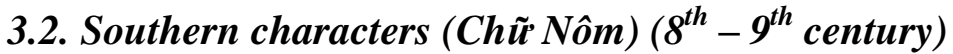

\subsubsection{History}

Southern Characters were created in the process of assimilation into Chinese script and considered as the brilliant cultural creation of Viet people, based on the Chinese terms.

Up to now, the researchers have found about 10,000 Southern characters, in the total 15,000 terms ever circulated.

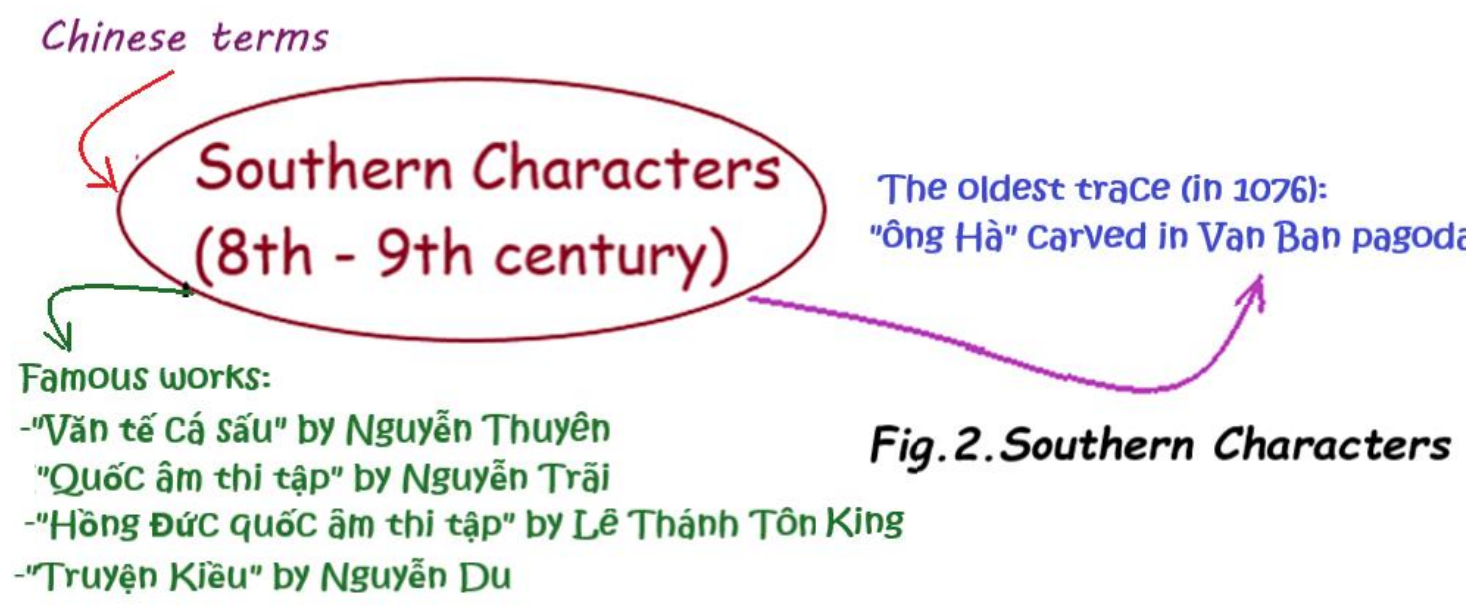


The earliest data about Southern characters were found in a text carved on a drum in Van Ban pagoda in 1076 under Ly dynasty.

In Tay Son dynasty, Southern characters became official language, used in formal documents.

Some famous works were written in Southern characters and by famous writers: Văn tế cá sấu by Nguyễn Thuyên, Quốc âm thi tập by Nguyễn Trãi, Hồng Đức quốc âm thi tập by Lê Thánh Tôn King, Truyện Kiều by Nguyễn $\mathrm{Du}, \ldots$

Southern characters became a relatively completed script in Tran dynasty (1226-1400) and strongly developed in 18th-19th century.

\subsubsection{Formation of Southern characters}

A Southern character $=2$ Chinese characters $=1$ main character to transcribe having the phonetic nearly similar to the phonetic reading of Vietnamese characters +1 character as radical to suggest and determine standard reading from Vietnamese characters.

Three methods of formation of Southern Characters:

\section{Counsel:}

Chinese word + Chinese word (having similar meaning)

Ex: “Trờ $i$ 昋 $($ Southern characters $)=$ "sky” 芺 $($ Chinese $)+$ “upper” 上 $($ Chinese $)$

\section{Mimicry:}

- Chinese word with classical Sino-Vietnamese reading

Ex. "Tuổi" 歲 (Southern characters) = “Tuế" 歲 (Chinese) with Sino-Vietnamese reading.

- Two Chinese words with Sino-Vietnamese reading

Ex. “Thi phi” 是非 $($ Southern characters $)=$ “thi ” 是 + “phi” 非 (Chinese with SinoVietnamese reading)

- A Chinese word with approximate sound

Ex. "Cô" 固 (Southern characters) = “Cố" (Chinese word meaning "strong enduring")

- A Chinese word semantically or phonetically modified.

Ex. "ấy" 代 (Southern characters) $\leftarrow$ 衣 (Chinese)

\section{Onomatopoeia:}

- Phono-semantic compound $=1$ word having same meaning + approximate sound Ex."3”巴 (Southern characters) $=$ “tam” 三 (semantic Chinese, meaning “3”) + “ba” 巴 (Sino-Vietnamese sound). 
“me” 媄 $($ Southern characters $)=$ “woman” 女 (semantic Chinese $)+$ “mỹ 美 (Sino-

Vietnamese sound)

- Radical + word sound

The above methods had to get Chinese terms or Chinese phonetic reading to create new Southern characters. Therefore, the users of Southern characters had to know and to be good at Chinese to learn and write Southern characters.

According to Nguyen Tai Can and Stankevitch (1981) in "Chũ Nôm, một thành tưu văn hoá của thời đại Lý Trần", only 3 scripts in the world were certainly created independently: ancient Egyptian script in Nile basin, Mai-a script in Central America and Chinese script in Yellow River basin. Other scripts are borrowed, from imitating some background script and adjusting more or less in accordance with private requirements. In reality, Southern characters were created by borrowing one or more Chinese elements and its appearance was a cultural success from early $10^{\text {th }}$ century to $15^{\text {th }}$ century, despite the assimilation into Chinese of Chinese domination. The relative and then strong usage of Southern characters expressed Viet people's effort of localization in the process of globalization.

\subsection{Vietnamese Script}

This part is based mostly on the series of articles in Tuoi Tre newspaper concerning the formation and development of Vietnamese script.

\subsubsection{Latinizing Vietnamese}

Based on remained documents written in 1621, Vietnamese script or An Nam script written in Latin alphabet might be invented in 1620 or before.

From the conference "Dinh trấn Thanh Chiêm and chữ quốc ngữ" in Quang Nam province on August 24, 2016, various opinions stated that it was Francisco de Pina, a Portuguese Jesuit, that settled the foundation of the birth of Vietnamese script and Jesuit Alexandre de Rhodes was the person who completed Vietnamese script through the composition, amendment and publication of the two books "Tù diển Việt-Bồ-La" (Dictionnaire Annamite Latin Portugais) and "Phép giảng tám ngày" (Catechisme en Latin et en Annam) in 1651.

Francisco de Pina was a Portuguese, so the basis for him to Latinize Vietnamese words might be the alphabet of Portuguese, in which the phoneme $\mathrm{z}$ was spelled differently from French ones, so he did not want to use $\mathrm{z}$, instead of d. The phonemes $\mathrm{x}, \mathrm{s}, \mathrm{ng}$, ngh, nh and the letters â, ê, ô also came from the alphabet of Portuguese.

In the two centuries (15-17), Portuguese businessmen travelled around the world and the missionaries, mostly Portuguese and Italian, came with them to preach in remote regions.

In the second half of the $16^{\text {th }}$ century, the Jesuit missionaries came to Asia to preach, 
one of their destinations was China.

Society of Jesus is an intellectual Roman Catholic religious order and all the Jesuits have to have doctoral level. Originated from countries using Latin script, the Jesuits got much difficulty in preaching to indigenous people in the countries using hieroglyph and the preaching was sometimes banned by local governments.

To be able to easily and better preach, the priests created the method of "Latinizing the hieroglyph" and applied it in India, China and Japan. In early $17^{\text {th }}$ century, some Jesuits coming to Hoi An had to speak Chinese and Japanese to communicate with local people through businessmen's translation.

Portuguese Jesuit Francesco de Pina came to Hoi An and Nuoc Man (Binh Dinh province) and lived in Thanh Chiem (Quang Nam province), began learning Vietnamese and became the Western person using Vietnamese the best at that time.

In 1615 , early $17^{\text {th }}$ century, the Jesuits came to Đàng Trong and gradually learned Vietnamese and began Latinizing Vietnamese script. Priest Do Quang Chinh divided the process of formation of Vietnamese scripts into two periods: 1620-1626 and 1631-1648.

a. The first period (1620-1626): jointly written terms

From the remained data, in the first period of Latinizing, the Vietnamese terms were written jointly, most of which had no accents and sometimes used accents.

Ex. Nuocman (Nước Mặn), Ainam (Hải Nam), Quanghia, Quamnguya (Quảng Nghĩa), Quignhin (Qui Nhơn), ...

From the beginning, some Vietnamese terms were written disjointly. For example, Sayc Chiu (sách chữ); scin mocaij (xin một cái); $D a$, an, het (đã ăn hết), Dàdèn Lùt (đã đến lụt); Tuijciam, Biet (tụi/tôi chẳng biết),..

Portuguese Jesuit João Roiz's document written in 1621 had some initial Vietnamese words: An Nam (Đàng Trong), Sinoa (xứ Hoá or Thuận Hoá), unsai (ông sãi), Cacham (Kẻ Chàm), ungue (ông nghè)...

In Portuguese Gapar Louis's document written in 1621: ungué (ông nghè), bancô (bàn cổ).

\section{b. The second period (1631-1648): disjointly written terms}

In the second period, the Jesuits wrote the Vietnamese words and phrases disjointly. Most of the words did not have accents yet, but some words were still jointly written and some had accents.

The important contribution of Portuguese Jesuit Gaspar d'Amaral: adding the Greek accents and the character " " $\vec{d}$ " in Latin alphabet.

Tuoi Tre article entitled "Thuỏ ban đầu của chĩ quốc ngưu" listed some Vietnamese words written in 1632-1637 by Jesuit G.d'Amaral: Đàng tlaõ (Đàng Trong), Đàng 
ngoày (Đàng Ngoài), Đàng tlĉn (Đàng Trên), nhà huyen (nhà huyện), oũ Khỏũ (ông Khổng/Khổng Tử), đức vuoong (đức vương), Sãy (sãi/sư sãi),...

To know about the success of the newly created Vietnamese script, the following column on the left are some paragraphs in the book entitled "Catechism en Latin et en Annam" written by A. Rhodes in 1651, in comparison with the adjusted paragraphs on the right.

TABLE 2. "Catechisme en Latin et en Annam" written in 1651 and today

\section{Writing in 1651}

« Phép giảng tám ngày : Ngày thứ nhít. Ta cãu cũ đức Chúa blời giúp fức cho ta bíet tó tưãng đạo Chúa là nhưãng nào vì bậy ta phải hay ở thế nầy chảng có ai fóu âu ; vì chưng kẻ đến bảy tám mươi tuỡi chảng cò nhẽo, vì bậy ta nên tìm đàng nào cho ta được fò̀u lâu, là kièm hàng fòu bậy : thật là viẹ người cuên tử, khác phép thế gian nầy, dù mà làm cho người được phú quý : fau le chảng làm được cho ta ngày fau...»

\section{Today Writing}

«Phép giảng tám ngày. Ngày thứ nhất. Ta cầu cúng đức Chúa trời giúp sức cho ta biết tở tường đạo Chúa nhường nào, vì vậy ta phải hay $0^{3}$

thế này chẳng có ai sống lâu, vì chưng kẻ đến bảy tám mươi tuổi chẳng có nhiều, vì vậy ta nên tìm đàng nào cho ta được sống lâu là kièm hàng sống vậy: thật là việc người quân tử khác phép thế gian này, dù mà làm cho người được phú quý: song le chẳng làm được cho ta ngày sau...»"

« Có kẻ thì nói ràng, bí bàng ta chảng thờ blời, mà blời lếy fãm fét đánh ta, hàn làm fao cho khỏi ? ấy là lo quéi, nào blời có đánh được ai đâu ?...»
«Có kẻ thì nói rằng, ví bằng ta chẳng thờ trời, mà trời lấy sấm sét đánh ta, hầu làm sao cho khỏi ? ấy là lo quấy (bậy bạ), nào trời có đánh được ai đâu ?... »

\subsubsection{The first newspaper and the first chief editor}

In April 1865, GIA ĐINH BÁO, the first newspaper in Vietnamese script, appeared with news, prices of many products and some useful concepts for native people. The paper was published monthly and free in schools to help good students in villages read papers. Petrus Truong Vinh Ky, the principal of Bổn Quốc high school (Le Qui Don school today), was delegated the responsibilities equaling to the first chief editor of the first paper in Vietnamese script.

Four years after publication, GIA ĐINH BÁO came weekly and each paper had 2 parts: the formal part consisted of documents, decisions in French of General and the Government furnished by Interior Service, the unformal part consisted of the helpful and cheerful texts about the historical issues, the moral events, breaking news... in order to read in native schools and attract Vietnamese people's interest. 


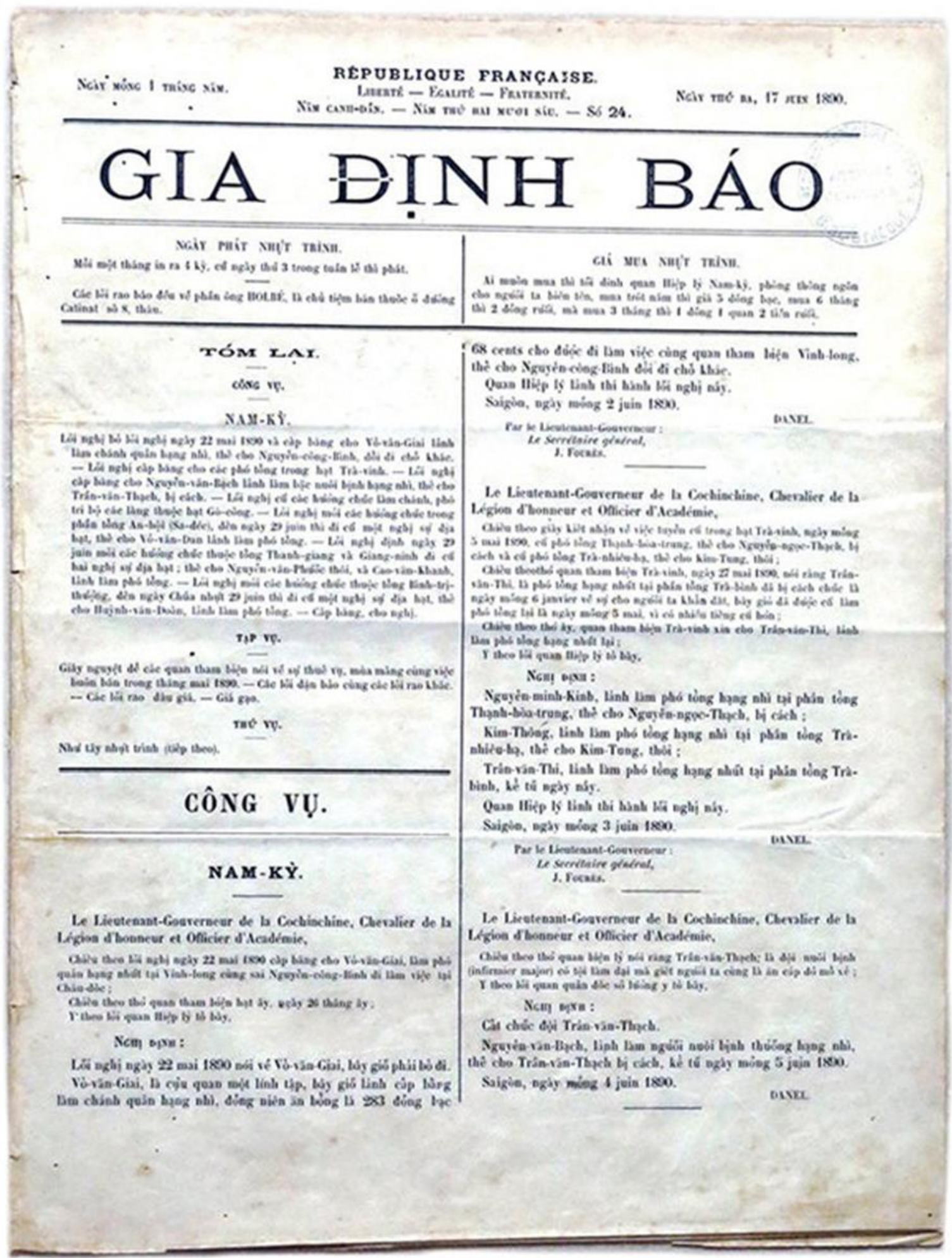

Figure 3. The first page of Gia Dinh Bao (Source: Tuoi Tre newspaper)

\subsection{Vietnamese words with French origin}




\subsubsection{French domination}

In the history of Vietnam, French domination was a period of 61 years, from 1884 to 1945, finished by the Japanese invasion. In French domination, due to interaction among Vietnamese and French people, original French words were Vietnamized and created in the following ways:

- Totally new words: "ren" for "dentelle", "tấn" for "tonne", "vải phin" for "toile fine", "cà phê phin"- "café filtre", "dăm bông" - "jambon", "bà đầm" - "madame", "cà-vạt" "cravatte", "anh lo" - "contrôleur", "bù-lon" - "boulon", "xăng" - "essence", "đường rầy" - "rail", "xe buýt"- "bus",...

- Translate French words: "thức uống lạn" from "consommé froid", "xe hoi" "machine à vapeur"...

- Vietnamese noun + Vietnamese adjective "tây": "măng tây" for "asperge", "gà tây" for "dinde, dindon".

- French words with Vietnamese pronunciation.

For example: "cùi dìa, thìa" for "cuillère", "xà-bông/xà-phòng" for "savon", "à-la-mốt" for "à la mode", "ba hoa chích choè" for "bavard comme une pie/un perroquet", "a-lô" for "allo", "áp-phích" for "affiche", "áp-phe" for "affaire", "ăng-ten" for "antenne", "ban-công" for "balcon", "bê-tông" for "béton", "bu-gi" for "bougie", "cao su" for "caoutchouc", "tà vet" for "traverse", "sếp" for "chef", "cúp cua" - "couper le cours", "xúp, súp" - "soupe", "xà lách" - "salade", "lê-ghim" - "légume", "tách" - "tasse", "sâm-banh" - "champagne", "cà-râ" - "carat", "ba-tê" - "pâté", "hột gà ốp la"- "oeuf au plat", "xích lô" - "cyclo", "đi văng" - "divan", "len" - "laine", "các tông" "carton", "lô" - "lot", "tem" - "timbre", "ô-liu"- "olive". "lò-xo" - "resort", "xúc xích" - "saucisse", "xúp-lêe" - "siffler", "bi” - "bille", "ô tô" - "auto", "tắc xi” - "taxi” .. .

The process of Vietnamizing French words requires some rules at any rate as mentioned in "Dictionnaire des termes vietnamiennes d'etymologie française" (Từ điển các từ tiếng Việt gốc Pháp) (Nguyễn Quảng Tuân \& Nguyễn Đức Dân, 1992), such as transforming the sounds of "ch, s" to "s, x" (sếp, súp/xúp...), borrowing the French pronunciation with Vietnamese accents (xích lô, buýt,..), reading with French phonetics (cua, ô tô...), transforming to accord with Vietnamese rhymes (tem, xúc xích...)..

The usage of Vietnamese words with French origin is an evidence of localization to get the Viet people's own Vietnamese from borrowing the French words and to make Vietnamese language more varied in Vietnamese way.

\subsection{Language of Teenage (Language @)}

Language of Teenage or Language @ is a tendency in the modern time with the development of Internet and technological devices such as mobile phone, smart phone, 
computer, laptop, wifi,...

The reasons for the use of Language of Teenage may be to save time, to show personal characters, to create new strange things... Today, not only teenagers but other Vietnamese people also use it to mail to each other.

Nguyen Thi Hai, linguistic researcher in Thu Dau Mot University, distinguishes two forms of abbreviation in Language of Teenage: auto generated and conventional, as in the following reduced table.

For the auto generated abbreviation, only some common words are used and between the members in the group. For the conventional abbreviation, there are rules for vowel sounds, initial letters and final letters.

TABLE 3. Auto-generated and conventional abbreviations

\begin{tabular}{|c|c|c|c|c|c|}
\hline \multicolumn{6}{|c|}{ Auto-generated } \\
\hline Đi & $\rightarrow$ & $\mathrm{dj}$ & Gì & $\rightarrow$ & $\mathrm{j}$ \\
\hline Không & $\rightarrow$ & $\mathrm{o}, \mathrm{ko}, \mathrm{k}, \mathrm{kh}, \mathrm{kg}$ & O & $\rightarrow$ & $\mathrm{u}$ \\
\hline Bây giờ & $\rightarrow$ & bi h & $\mathrm{A}$ & $\rightarrow$ & $\mathrm{e}$ \\
\hline Biết rồi & $\rightarrow$ & Bit rui & Em & $\rightarrow$ & $\mathrm{m}, \mathrm{e}$ \\
\hline \multicolumn{6}{|c|}{ Conventional abbreviation } \\
\hline \multicolumn{3}{|c|}{ Rewritten final consonants } & \multicolumn{3}{|c|}{ Examples } \\
\hline $\mathrm{G}$ & $\rightarrow$ & NG & Xoo & $\mathrm{g} ; \mathrm{ko}$ & ng mong \\
\hline $\mathrm{H}$ & $\rightarrow$ & $\mathrm{NH}$ & Hoa & ; bah & \\
\hline $\mathrm{K}$ & $\rightarrow$ & $\mathrm{CH}$ & Hoa & ; sal & \\
\hline
\end{tabular}

Language of Teenage is created simply for personal will, but it can express some hot trend in modern time, like the use of English words in Vietnamese daily life. These expressions result from globalization but honestly speaking, this type cannot improve Vietnamese characters, which means the failure of localization.

\subsection{Vietnamizing foreign words:}

Vietnamese people can Vietnamize and transform foreign words to Vietnamese terms. The changed or transcribed names of countries are used as Vietnamese words, without any foreign element.

- Pháp, Nga, Áo, Đức, Ý, Bỉ, Hà Lan, Ba Lan, Ba Tu, Án Độ, Luận Đôn, Đan Mạch

- Bồ Đào Nha, Tây Ban Nha, Hà Lan, Na Uy, Thuỵ Điển, Miến Điện, Đài Loan...

- I-rắc, Ác-hen-ti-na, Pa-le-xtin, Giê-ru-xa-lem, Xin-ga-po ...

Nowadays, when globalization prompts countries and people to connect and English is learned and used more and more comfortably, such usage of transformed foreign words or place names can finish and original foreign words are used despite their origins.

\subsection{English alternating with Vietnamese: Language of events, of phenomena}


In the present, with the development of high technologies, of communication and of Internet, Vietnamese people can easily travel and communicate with foreigners or read everything in English on Internet.

That is the reason why globalized English terms appear everywhere, from books, newspapers, documents or media to the shop signs, road-signs, especially along with the most important events or phenomena, such as World Cup, Olympic, coronavirus, Covid, lockdown, vaccine...

However, a phenomenon should not be left out, that is the public use of English words, on TV, on newspapers, on road signs,... or used in the Vietnamese names. For example, the English words like "hot girl, hot boy, hit, hot, online, show, showbiz, solo, netizens, football,.." or the names like "Đúc Vince, Elly Trần, Noo Phuoóc Thịnh, Soobin Hoàng...

- "Các trường 'hot' ở Hà Nội lùi tuyển sinh đầu cấp, có trường cho thi trực tuyến" (Tuoi Tre Online, May 26, 2021)

- "Dân làm tour du lịch 'gác kiếm', xoay nghề trong bão dịch COVID-19" (Tuoi Tre Online, May 24, 2021).

- "Nền tảng giao tiếp online 'made in Việt Nam' miễn phí cho doanh nghiệp làm việc từ xa" (Tuoi Tre Online, May 27, 2021)

“...một số cơ quan, doanh nghiệp chuyên môn trong nước đã sớm vào cuộc nghiên cứu, bào chế và thử nghiệm vắc-xin "made in Việt Nam" với những tín hiệu khả quan ban đầu. (Nguoi Lao Dong, May 21, 2021)

"Kinh doanh ăn uống giữ khách bằng khuyến mãi online" (Nguoi Lao Dong, December $16,2018)$

- "Doanh nghiệp ủng hộ quỹ vaccine có được ưu tiên tiêm trước?" (Zing, May 28, 2021)

Borrowing English words can be explained for saving time, for not having Vietnamese terms with equal meaning or even for demonstrating the capacity of using English or creating new Vietnamese, However, with the rather high level of using English nowadays, Vietnamese people certainly understand such borrowed English terms and they even do not pay attention to the origin of these borrowed English terms. Therefore, when English is the most popular language in the world, like a symbol of globalization of language, along with the advancement of technologies and the presence of Internet, of social media and websites, the problem of Vietnamizing English or the appearance of dual languages may not be raised, simply because globalization now becomes the everpresent trend for all the world. 


\section{Conclusion}

In conclusion, Vietnamese language has been changed a lot from its formation until the present time. The different transformations due to foreign dominations and Vietnamese people's effort result in a more beautiful language. How, what and where to change depend on historical periods, on dominators, on French, English or Vietnamese levels. After thousands of years, Vietnamese language is now felt as perfect but it can be improved and protected much better to enhance localization in globalization.

The current use of English in Vietnam is so popular that there has just been an opinion of choosing English as the second language in Vietnam (Nguoi Lao Dong, "Lắng nghe người dân hiến kế: Đặt tiếng Anh làm ngôn ngũ thư hai của TP HCM", May 28, 2021). This idea is considered as a way of eliminating the barrier of language for integration, which is totally different from the effort to uphold Vietnamese characteristics in Vietnamese language. However, such change in points of view is necessary and really suitable for modern life and for the era.

\section{References}

Đào Duy Anh. (1975). Chũ Nôm: Nguồn gốc, cấu tạo, diến biến. Hà Nội: Nhà Xuất bản Khoa học Xã hội.

Hoàng Xuân Hãn. (1959). Văn kiện bằng chữ Quốc Ngữ tang trữ ở châu Âu. Tạp chi Đại học, số 10 .

Huỳnh Thị Hồng Hạnh \& Nguyễn Thị Thu Trang. (eds.). (2016). Chũ Quốc Ngũ: Sụ Hình Thành, Phát Triển và Đóng góp vào Văn Hoá Việt Nam. TP HCM: Nxb Đại học Quốc gia TPHCM

Huỳnh Văn Mỹ (2014). Thuở ban đầu của chữ quốc ngũ. Tuoi Tre newspaper, April $18^{\text {th }}$.

Lã Minh Hằng (2004). Cấu trúc nghĩa trong chĩ Nôm-Việt. HN: Nhà Xuất bản Khoa học Xã hội.

Lê Trung (2019). Alexandre de Rhodes không phải là "cha đẻ" chữ quốc ngữ? Tuoi Tre newspaper, August $25^{\text {th }}$.

Nguyễn Duy Hinh (2019). Văn minh Đại Việt. HN: Nhà Xuất bản Hồng Đức.

Nguyễn Hữu Phước. (2005). Chũ Việt Gốc Pháp. Retrieved from http://namkyluctinh.com/angonngu/nhphuoc-vietgocphap.pdf

Nguyễn Quảng Tuân \& Nguyễn Đức Dân. (1992). Tù điển các tù̀ tiếng Việt gốc Pháp (Dictionnaire des termes vietnamiens d'étymologie française. TP HCM: Hội Nghiên cứu và Giảng dạy Văn học.

Nguyễn Tài Cẩn \& Stankevitch, N.V. (1981). Chữ Nôm, một thành tựu văn hoá của thời đại Lý Trần. In Viện Sử học. Tìm hiểu xã hội Việt Nam thời Lý - Trần. HN: Nxb Khoa học xã hội

Phạm Văn Hải \& Lê Văn Đặng. (2005). Chũ Hán và tiếng Hán-Việt. USA: George Washington University. 
Rondinelli, Dennis, \& Heffron, John. (2007). Globalization and change in Asia. Boulder: Lynne Rienner

Trần Nhật Vy. Người có công đầu với chữ quốc ngữ - Kỳ 4: Nhà báo Trương Vĩnh Ký. Tuoi Tre newspaper, September $18^{\text {th }}, 2018$.

Trần Nhật Vy. Người có công đầu với chữ quốc ngữ - Kỳ 4: Nhà báo Trương Vĩnh Ký. Tuoi Tre newspaper, September $18^{\text {th }}, 2018$

Trần Văn Kiệm. (2004). Giúp đọc Nôm và Hán-Việt. Đà Nẵng: Nhà Xuất bản Đà Nẵng.

Trương Đức Quả. (1997). Nghiên cưu mối tưong quan giữa âm Hán-Việt với âm Nôm trong cách đọc chĩ Nôm. HN: Viện Nghiên cứu Hán-Nôm.

Viện Ngôn ngữ học. (1976). Bảng tra cúu chũ Nôm. Hà Nội: Nhà Xuất bản Khoa học Xã hội.

Vũ Thế Khôi. (2006). Triệu Đà với công cuộc truyền bá chũ Hán vào Việt Nam. Tạp chí Xưa \& Nay - Số 265. Retrieved from: https://xuanay.vn/trieu-da-voi-cong-cuoc-truyen-ba-chuhan-vao-viet-nam/ 